Sains Malaysiana 49(2)(2020): 223-236

http://dx.doi.org/10.17576/jsm-2020-4902-01

\title{
Ciri Fizikal dan Mikroskopi Anatomi Kayu Malvaceae Subfamili Bombacoideae dan Helicteroideae
}

(Physical and Microscopic Anatomical Characteristics of Malvaceae Woods Subfamilies Bombacoideae and Helicteroideae)

\author{
Nordahlia Abdullah Siam*, Noraini Talip, Richard Chung Cheng Kong \& Lim Seng Choon
}

\section{ABSTRAK}

Kajian mengenai ciri fizikal dan mikroskopi anatomi kayu telah dijalankan pada 36 spesies Malvaceae subfamili Bombacoideae (genus Bombax) dan Helicteroideae (genus Coelostegia, Durio, Kostermansia dan Neesia) di Malaysia. Objektifkajian ini ialah untuk menentukan kesesuaian penempatan genus Bombax dan Coelostegia, Durio, Kostermansia dan Neesia di bawah subfamili berbeza iaitu Bombacoideae and Helicteroideae dengan membandingkan hasil analisis fenetik berangka dan pengelasan berdasarkan molekul DNA; menentukan kesesuaian penempatan kelompok Helicteroideae: Durioneae di bawah subfamili Helicteroideae bersama dengan genus kelompok Helicteroideae s.s.; dan menyemak status Boschia sama ada sebagai genus tersendiri atau perlu digabungkan dengan Durio. Hasil analisis fenetik berangka menyokong cadangan pengelasan berdasarkan molekul DNA yang mengasingkan Bombax (Bombacoideae) daripada subfamili Helicteroideae. Keputusan analisis fenetik berangka juga menunjukkan bahawa kelompok Helicteroideae: Durioneae (Coelostegia, Durio, Kostermansia dan Neesia) perlu dikeluarkan daripada subfamili Helicteroideae dan dicadangkan untuk diletakkan di bawah subfamili baharu iaitu Durionoideae. Sebaliknya, kajian ini menolak cadangan pengelasan yang menaikkan subfamili Bombacoideae kepada famili Bombacaceae, subfamili Helicteroideae s.s. kepada famili Helicteradaceae dan subfamili Helicteroideae: Durioneae kepada famili Durionaceae. Hasil analisis fenetik berangka menunjukkan Boschia perlu digabungkan dengan Durio.

Kata kunci: Analisis fenetik berangka; anatomi kayu; Bombacoideae; Helicteroideae; Malvaceae

\section{ABSTRACT}

Studies on the physical and microscopic anatomical characteristics of woods were carried out on 36 species of Malvaceae subfamilies Bombacoideae (genus Bombax) and Helicteroideae (Coelostegia, Durio, Kostermansia and Neesia) in Malaysia. The objectives of this study were to construct groups using numerical phenetic analysis to compare with the classifications of DNA molecular studies, to investigate either Bombax should be separated from Coelostegia, Durio, Kostermansia and Neesia, or should be placed under different subfamilies which are Bombacoideae and Helicteroideae, respectively. In addition to that, to see the suitability of the Helicterodeae: Durioneae group to put under the subfamily Helicteroideae together with the Helicteroideae s.s. group. Moreover, to see the suitability of family concept, proposed by previous study. Besides that, to determine whether Boschia should stand as individual genus or it should be combined with Durio. Based on numerical phenetic analysis this study supports the concept of classification of molecular DNA that separates Bombax from Coelostegia, Durio, Kostermansia and Neesia and placed under different subfamilies. However, this numerical phenetic analysis shows that the Helicteroideae: Durioneae group (Coelostegia, Durio, Kostermansia and Neesia) should be removed from the subfamily Helicteroideae and proposed to be placed in a new subfamily which is Durionoideae. On the other hand, the present study disagrees with previous classification that upgraded the subfamily Bombacoideae to family Bombacaceae, subfamily Helicteroideae s.s. to family Helicteradaceae and subfamily Helicteroideae: Durioneae to family Durionaceae. Our numerical phenetic analysis suggest the genus Boschia to be combined with Durio.

Keywords: Bombacoideae; Helicteroideae; Malvaceae; numerical phenetic analysis; wood anatomy

\section{Pengenalan}

Berdasarkan kajian DNA molekul, empat famili utama dalam order Malvales iaitu Bombacaceae s.l., Malvaceae, Sterculiaceae dan Tiliaceae sewajarnya digabungkan dan diletakkan di bawah Malvaceae (Bayer \& Kubitzki 2003; Bayer et al. 1999). Famili ini seterusnya dibahagikan kepada sembilan subfamili iaitu Bombacoideae,
Brownlowioideae, Byttnerioideae, Dombeyoideae, Grewioideae, Helicteroideae, Malvoideae, Sterculioideae dan Tilioideae. Bombax L., Coelostegia Benth., Durio Adan., Kostermansia Soegeng dan Neesia Blume yang pada asalnya diletakkan di bawah satu famili yang sama iaitu Bombacaceae s.l. telah dipecahkan kepada dua subfamili iaitu Bombacoideae dan Helicteroideae. Bombax 
diletakkan di bawah subfamili Bombacoideae manakala Coelostegia, Durio, Kostermansia dan Neesia diletakkan di bawah subfamili Helicteroideae. Menurut Bayer dan Kubitzki (2003) subfamili Helicteroideae terbahagi kepada dua kelompok iaitu Helicteroideae s.s. yang terdiri daripada Helicteres L., Mansonia A. Chev., Neoregnellia Urb., Reevesia Lindley, Triplochiton Schum. dan Ungeria Schott \& Endle. dan juga kelompok Helicteroideae: Durioneae yang terdiri daripada Coelostegia, Durio, Kostermansia, Neesia, Boschia Korth. dan Cullinea Wight. Cheek (2007, 2006) mencadangkan kelompok Helicteroideae s.s. yang terdiri daripada Helicteres, Mansonia, Neoregnellia, Reevesia, Triplochiton dan Ungeria dinaik taraf kepada famili Helicteradaceae. Manakala kelompok Helicteroideae: Durioneae yang terdiri daripada Coelostegia, Durio, Kostermansia, Neesia, Boschia dan Cullinea dinaik taraf kepada Durionaceae. Bombax daripada subfamili Bombacoideae pula dinaik taraf kepada famili Bombacaceae S.S.

Analisis fenetik berangka ialah kaedah yang digunakan untuk tujuan pengelompokan, pengelasan dan penentuan hubungan antara takson berdasarkan kesamaan fenetik (Johnson 1982). Kaedah ini telah digunakan secara meluas pada tumbuhan tinggi dan telah menunjukkan hasil yang signifikan dalam menyelesaikan masalah taksonomi (Sneath 1976). Berdasarkan kajian lepas oleh Duncan dan Baum (1981), analisis ini telah digunakan pada peringkat spesies malah telah juga digunakan pada peringkat takson yang lebih tinggi dan lebih khusus kepada tumbuhan berbunga. Selain itu, analisis fenetik berangka juga digunakan dalam kajian anatomi kayu bagi tujuan pengelasan (Herenden \& Miller 2000; Meeuse 1982).

Objektif kajian ini adalah untuk membentuk kumpulan menggunakan analisis fenetik berangka berdasarkan ciri fizikal dan mikroskopi anatomi kayu untuk dibandingkan dengan pengelasan DNA molekul oleh Bayer et al. (1999) dan Bayer dan Kubitzki (2003), untuk melihat sama ada Bombax dipisahkan daripada Coelostegia, Durio, Kostermansia dan Neesia dengan masing-masing diletakkan di bawah subfamili yang berbeza iaitu Bombacoideae dan Helicteroideae. Selain itu, untuk melihat kesesuaian Coelostegia, Durio, Kostermansia dan Neesia diletakkan di bawah subfamili Helicteroideae bersama dengan Helicteres, Mansonia, Neoregnellia, Reevesia, Triplochiton dan Ungeria (Bayer et al. 1999; Bayer \& Kubitzki 2003). Kesesuaian cadangan pengelasan Cheek $(2007,2006)$ juga dikaji. Kajian ini juga bertujuan untuk menentukan status Boschia sama ada sebagai genus tersendiri (Bayer \& Kubitzki 2003; Bayer et al. 1999) atau patut digabungkan dengan Durio (Ashton 1988; Bakhuizen van den Brink 1924; Kochummen 1972; Kostermans 1958; Salma 2011).

\section{BAHAN DAN KAEDAH}

Fenogram dibina melalui kaedah analisis UPGMA dengan menggunakan perisian MVSP versi 3.1 oleh Kovach Technology ke atas 36 spesies seperti yang disenaraikan dalam Jadual 1 daripada sepuluh genus iaitu Bombax (subfamili Bombacoideae), Coelostegia, Durio, Kostermansia, Neesia, Cullinea, Helicteres, Mansonia, Reevesia dan Triplochiton (subfamili Helicteroideae). Cullinea, Helicteres, Mansonia, Reevesia dan Triplochiton merupakan genus tambahan yang dimasukkan dalam analisis fenetik sebagai 'out group' bagi tujuan perbandingan dengan genus kajian ini iaitu untuk melihat kesesuaian Coelostegia, Durio, Kostermansia dan Neesia diletakkan di bawah subfamili Helicteroideae bersama dengan Helicteres, Mansonia, Neoregnellia, Reevesia, Triplochiton dan Ungeria (Bayer \& Kubitzki 2003; Bayer et al. 1999). Data kelima-lima genus ini adalah berdasarkan rujukan terdahulu seperti pada Jadual 3. Ciri yang dipilih untuk analisis fenetik berangka merupakan ciri yang mempunyai nilai taksonomi, tidak dipengaruhi oleh persekitaran, tidak bersifat keplastikan dan tidak terdapat pemberat bagi ciri yang tertentu. Bilangan ciri yang digunakan dalam kajian ini ialah 54 ciri iaitu gabungan ciri fizikal dan mikroskopi anatomi kayu.

Ciri fizikal yang dicerap ialah kehadiran tanda riak, tekstur dan ketumpatan kayu. Kehadiran ciri tanda riak dilihat menggunakan kanta tangan dengan pembesaran 10 $\mathrm{x}$ pada permukaan memanjang tangen kayu. Tekstur kayu dicerap menggunakan mata kasar terhadap permukaan kayu yang telah diketam atau dilicinkan. Manakala ketumpatan kayu diukur menggunakan kaedah berat kering relau per isi padu. Slaid mikroskopi disediakan berdasarkan Schweingruber et al. (2006). Proses maserasi pula adalah berdasarkan Wheeler et al. (1989). Pemerhatian mikroskopi dan pengukuran struktur kayu dilakukan menggunakan mikroskop cahaya mengikut huraian dan terminologi oleh Menon (1971) dan Wheeler et al. (1989). Bagi penyediaan sampel untuk tujuan cerapan di bawah mikroskop imbasan elektron, adalah berdasarkan Jansen et al. (1998). Terminologi dan huraian adalah berdasarkan Jansen et al. (2000), Nair (1998), Richter (1981) dan Ter Welle (1976).

\section{HASIL DAN PERBINCANGAN}

\section{PENGELOMPOKAN DALAM ANALISIS FENETIK BERANGKA PERINGKAT SUBFAMILI}

Fenogram yang terhasil daripada analisis fenetik berangka berdasarkan ciri fizikal dan mikroskopi anatomi kayu telah membentuk dua kumpulan (Rajah 1). Kumpulan pertama menunjukkan Bombax yang mewakili subfamili Bombacoideae jelas terpisah daripada kumpulan kedua iaitu subfamili Helicteroideae. Bombax terpisah daripada Coelostegia, Durio, Kostermansia dan Neesia (subfamili Helicteroideae: Durioneae). Mengikut pengelasan tradisi kelima-lima genus ini diletakkan bersama di bawah Bombacaceae s.l. Hasil kajian ini menyamai pengelasan Bayer dan Kubitzki (2003) dan Bayer et al. (1999) yang juga menunjukkan Bombax jauh terpisah daripada empat genus subfamili Helicteroideae: Durioneae yang lain. Oleh yang demikian, hasil kajian ini jelas menyokong pengelasan subfamili berdasarkan kepada jujukan DNA molekul oleh Bayer dan Kubitzki (2003) dan Bayer et al. (1999) dengan Bombax dipisahkan daripada Coelostegia, 
JADUAL 1. Senarai 36 spesies kajian ciri fizikal dan mikroskopi anatomi kayu Malvaceae

\begin{tabular}{|c|c|c|c|c|}
\hline Spesies & Lokaliti & Nombor rujukan & Nombor xylarium & Xylarium \\
\hline \multicolumn{5}{|l|}{ Genus Bombax } \\
\hline B. anceps & $\begin{array}{l}\text { Kedah, Langkawi, Pulau Pasir } \\
\text { Kedah, Langkawi, Bukit Sawak FR }\end{array}$ & $\begin{array}{l}\text { FRI } 82773 \\
\text { FRI } 82776\end{array}$ & $\begin{array}{l}\text { wt10178 } \\
\text { wt10181 }\end{array}$ & $\begin{array}{l}\mathrm{KEPw} \\
\mathrm{KEPw}\end{array}$ \\
\hline B. ceiba & $\begin{array}{l}\text { Vietnam, Tongking River } \\
\text { India } \\
\text { Sabah, Sandakan, Sepilok FR }\end{array}$ & $\begin{array}{c}- \\
- \\
\text { SAN } 157284\end{array}$ & $\begin{array}{l}\text { TWTw8494 } \\
\text { TWTw10810 } \\
\text { wt10194 }\end{array}$ & $\begin{array}{l}\text { TWTw } \\
\text { TWTw } \\
\text { KEPw }\end{array}$ \\
\hline B. valetonii & $\begin{array}{l}\text { Selangor, Gombak, Ulu Langat FR } \\
\text { Selangor, Gombak, Genting Sempah } \\
\text { Perak, Hulu Perak, Grik, } \\
\text { Selangor, Gombak, Kepong }\end{array}$ & $\begin{array}{l}\text { KEP } 65634 \\
\text { KEP } 9905 \\
\text { KEP } 11598 \\
\text { KEP } 44948\end{array}$ & $\begin{array}{c}\text { wt7233 } \\
\text { wt176 } \\
\text { wt696 } \\
\text { wt } 4466\end{array}$ & $\begin{array}{l}\text { KEPw } \\
\text { KEPw } \\
\text { KEPw } \\
\text { KEPw }\end{array}$ \\
\hline \multicolumn{5}{|c|}{ Genus Coelostegia } \\
\hline C. borneensis & $\begin{array}{l}\text { Sarawak, Bintulu, Similijau FR } \\
\text { Selangor, Gombak, Bukit Lagong FR }\end{array}$ & $\begin{array}{c}\text { S } 8631 \\
\text { KEP } 81089\end{array}$ & $\begin{array}{c}- \\
\text { wt684 }\end{array}$ & $\begin{array}{l}\text { SARFw } \\
\text { KEPw }\end{array}$ \\
\hline C. chartacea & Sabah, Lahad Datu, Ulu segama & SAN 157282 & wt10187 & KEPw \\
\hline C. griffithii & $\begin{array}{l}\text { Negeri Sembilan,Port Dickson, Pasir Panjang } \\
\text { Perak, Kuala Kangsar, Bubu FR } \\
\text { Johor, Batu Pahat, Banang FR } \\
\text { Kelantan, Machang, Temangan }\end{array}$ & $\begin{array}{l}\text { FMS } 4222 \\
\text { KEP } 86060 \\
\text { KEP } 70172 \\
\text { KEP } 68766\end{array}$ & $\begin{array}{l}\text { wt286 } \\
\text { wt8003 } \\
\text { wt8233 } \\
\text { wt } 9414\end{array}$ & $\begin{array}{l}\text { KEPw } \\
\text { KEPw } \\
\text { KEPw } \\
\text { KEPw }\end{array}$ \\
\hline C. montana & $\begin{array}{l}\text { Sabah, Kundasang, Rafflesia FR } \\
\text { Sabah, Kundasang, Rafflesia FR }\end{array}$ & $\begin{array}{l}\text { SAN } 157266 \\
\text { SAN } 157267\end{array}$ & $\begin{array}{l}\text { wt10186 } \\
\text { wt10187 }\end{array}$ & $\begin{array}{l}\mathrm{KEPw} \\
\mathrm{KEPw}\end{array}$ \\
\hline \multicolumn{5}{|l|}{ Genus Durio } \\
\hline D. affinis & Brunei, Bukit Rotan & FMS 34468 & wt4222 & KEPw \\
\hline D. carinatus & $\begin{array}{l}\text { Pahang, Kuantan, Gedong Rasam } \\
\text { Pahang, Kuantan, Pekan Road } \\
\text { Johor, Mersing } \\
\text { Sarawak, Sibu }\end{array}$ & $\begin{array}{l}\text { KEP } 6653 \\
\text { KEP } 43201 \\
\text { KEP } 70105 \\
\text { S } 23109\end{array}$ & $\begin{array}{c}\text { wt179 } \\
\text { wt3490 } \\
\text { wt6816 } \\
-\end{array}$ & $\begin{array}{l}\text { KEPw } \\
\text { KEPw } \\
\text { KEPw } \\
\text { SARFw }\end{array}$ \\
\hline D. dulcis & Sarawak, Lundu, Gunung Gading & S 15395 & - & SARFw \\
\hline D. excelsus & $\begin{array}{l}\text { Sarawak } \\
\text { Sarawak, Belaga, Ulu Sungai Semawit }\end{array}$ & $\begin{array}{l}\text { S } 80134 \\
\text { S } 43565\end{array}$ & $\begin{array}{l}- \\
-\end{array}$ & SARFW \\
\hline D. grandiflorus & Sabah, Kinabatangan & SAN 138994 & wt4743 & SARFW \\
\hline D. graveolens & $\begin{array}{l}\text { Perak, Kuala Kangsar, Kledang Saiong FR } \\
\text { Negeri Sembilan, Jempol, Serting FR } \\
\text { Sarawak, Lundu, Sg Snibong } \\
\text { Sarawak, Bintulu, Segan FR }\end{array}$ & $\begin{array}{l}\text { KEP } 8832 \\
\text { KEP } 62973 \\
\text { S } 9621 \\
\text { S } 15129\end{array}$ & $\begin{array}{c}\text { wt666 } \\
\text { wt6418 } \\
- \\
-\end{array}$ & $\begin{array}{l}\text { KEPw } \\
\text { KEPw } \\
\text { SARFw } \\
\text { SARFw }\end{array}$ \\
\hline D. griffithii & $\begin{array}{l}\text { Perak, Sungkai, Plus FR } \\
\text { Selangor, Gombak, Sungai Buluh FR } \\
\text { Negeri Sembilan, Senawang } \\
\text { Sarawak, Tatau, Bukit Mersing }\end{array}$ & $\begin{array}{l}\text { FMS } 39052 \\
\text { FMS } 45003 \\
\text { FMS } 1978 \\
\text { S } 22134\end{array}$ & & $\begin{array}{l}\text { KEPw } \\
\text { KEPw } \\
\text { KEPw } \\
\text { SARFw }\end{array}$ \\
\hline D. kinabaluensis & Sabah, Ranau, Poring & SAN 157280 & wt10188 & KEPw \\
\hline D. kutejensis & $\begin{array}{l}\text { Sarawak, Lundu, Gunung Pueh FR } \\
\text { Sarawak, Marudi, Bukit Mentagai }\end{array}$ & $\begin{array}{l}\text { S } 15682 \\
\text { S } 22848\end{array}$ & $\begin{array}{l}- \\
-\end{array}$ & $\begin{array}{l}\text { SARFW } \\
\text { SARFW }\end{array}$ \\
\hline D. lanceolatus & $\begin{array}{l}\text { Sarawak, Lundu, Gunung Gading } \\
\text { Sarawak, Marudi,Gunung Mulu National } \\
\text { Park }\end{array}$ & $\begin{array}{l}\text { S } 15373 \\
\text { S } 13630\end{array}$ & - & $\begin{array}{l}\text { SARFw } \\
\text { SARFw }\end{array}$ \\
\hline D. lowianus & $\begin{array}{l}\text { Perak, Hulu Perak, Sumpitan } \\
\text { Pahang, Rompin, Mentas FR } \\
\text { Kedah, Kuala Muda, Gunung Jerai FR } \\
\text { Johor, Batu Pahat, Soga FR }\end{array}$ & $\begin{array}{l}\text { KEP } 10421 \\
\text { KEP } 31700 \\
\text { KEP } 59642 \\
\text { KEP } 70153\end{array}$ & $\begin{array}{r}\text { wt669 } \\
\text { wt4843 } \\
\text { wt8193 } \\
\text { wt8238 }\end{array}$ & $\begin{array}{l}\text { KEPw } \\
\text { KEPw } \\
\text { KEPw } \\
\text { KEPw }\end{array}$ \\
\hline D. macrophyllus & $\begin{array}{l}\text { Perak, Sg Siput } \\
\text { Perak, Kuala Kangsar, Senat }\end{array}$ & $\begin{array}{l}\text { KEP } 8836 \\
\text { KEP } 127\end{array}$ & $\begin{array}{l}\text { wt668 } \\
\text { wt125 }\end{array}$ & $\begin{array}{l}\mathrm{KEPw} \\
\mathrm{KEPw}\end{array}$ \\
\hline D. malaccensis & Selangor, Gombak, FRIM & KEP 16757 & wt4433 & KEPw \\
\hline D. oblongus & Sarawak, Bau, Bungo Range & S 28996 & - & SARFw \\
\hline
\end{tabular}




\begin{tabular}{|c|c|c|c|c|}
\hline D. oxleyanus & $\begin{array}{l}\text { Selangor, Batang Padang, Behrang FR } \\
\text { Kedah, Sik } \\
\text { Johor, Batu Pahat }\end{array}$ & $\begin{array}{l}\text { KEP } 61148 \\
\text { KEP } 73842 \\
\text { KEP } 79409\end{array}$ & $\begin{array}{l}\text { wt8195 } \\
\text { wt8198 } \\
\text { wt8241 }\end{array}$ & $\begin{array}{l}\text { KEPW } \\
\text { KEPW } \\
\text { KEPW }\end{array}$ \\
\hline D. perakensis & Perak, Kuala Kangsar, Piah FR & FRI 2455 & wt5840 & KEPw \\
\hline D. pinangianus & Kedah, Sik, Bukit Enggang FR & KEP 83814 & wt8200 & KEPw \\
\hline D. singaporensis & $\begin{array}{l}\text { Pahang, Temerloh, Kemasul FR } \\
\text { Selangor, Gombak, Genting Sempah } \\
\text { Johor, Panti FR } \\
\text { Terengganu, Dungun }\end{array}$ & $\begin{array}{l}\text { FMS } 10573 \\
\text { KEP } 34258 \\
\text { KEP } 93681 \\
\text { KEP } 57405\end{array}$ & $\begin{array}{l}\text { wt248 } \\
\text { wt3731 } \\
\text { wt9978 } \\
\text { wt6362 }\end{array}$ & $\begin{array}{l}\mathrm{KEPW} \\
\mathrm{KEPW} \\
\mathrm{KEPW} \\
\mathrm{KEPW}\end{array}$ \\
\hline D. testudinarum & Sabah, Sandakan, Sepilok FR & SAN 157275 & wt10190 & $\mathrm{KEPw}$ \\
\hline D. wyatt-smithii & Brunei, Bukit Paka & KEP 37071 & wt5340 & KEPw \\
\hline D. zibethinus & $\begin{array}{l}\text { Selangor, Hulu Selangor, Batang Kali FR } \\
\text { Perak, Kinta, Chemor } \\
\text { Sabah, Sandakan, Sepilok FR } \\
\text { Sabah, LungManis }\end{array}$ & $\begin{array}{l}\text { KEP } 64204 \\
\text { KEP } 65944 \\
\text { A } 2879 \\
\text { SAN } 65612\end{array}$ & $\begin{array}{l}\text { wt8221 } \\
\text { wt8235 } \\
\text { wt6149 } \\
\text { wt2 } 106\end{array}$ & $\begin{array}{l}\text { KEPw } \\
\text { KEPW } \\
\text { KEPw } \\
\text { SANw }\end{array}$ \\
\hline \multicolumn{5}{|l|}{ Genus Kostermansia } \\
\hline K. malayana & $\begin{array}{l}\text { Pahang, Rompin, Sg Anak Endau } \\
\text { Pahang, Rompin, Sepayang Ulu Pontian } \\
\text { Kelantan } \\
\text { Perak, Batang Padang, Bikam FR }\end{array}$ & $\begin{array}{l}\text { KEP } 31606 \\
\text { KEP } 10007 \\
\text { KEP } 50651 \\
\text { KEP } 61080\end{array}$ & $\begin{array}{l}\text { wt2528 } \\
\text { wt4400 } \\
\text { wt5691 } \\
\text { wt8231 }\end{array}$ & $\begin{array}{l}\mathrm{KEPW} \\
\mathrm{KEPW} \\
\mathrm{KEPW} \\
\mathrm{KEPW}\end{array}$ \\
\hline \multicolumn{5}{|l|}{ Genus Neesia } \\
\hline N. altissima & $\begin{array}{l}\text { Perak, Parit } \\
\text { Perak, Sg. Krian Estate }\end{array}$ & $\begin{array}{l}\text { KEP } 31699 \\
\text { SFN } 36737\end{array}$ & $\begin{array}{l}\text { wt4873 } \\
\text { wt4704 }\end{array}$ & $\begin{array}{l}\mathrm{KEPW} \\
\mathrm{KEPW}\end{array}$ \\
\hline N. kostermansiana & $\begin{array}{l}\text { Perak, Sg Larut } \\
\text { Selangor, Kuala Selangor, Sg Tinggi } \\
\text { Perak, Larut, Tanjong FR } \\
\text { Perak, Sungkai, Changkat Jong FR }\end{array}$ & $\begin{array}{l}\text { Wray } 2271 \\
\text { SFN } 34121 \\
\text { KEP } 63466 \\
\text { FRI } 69007\end{array}$ & $\begin{array}{l}\text { wt194 } \\
\text { wt3807 } \\
\text { wt8240 } \\
\text { wt9960 }\end{array}$ & $\begin{array}{l}\mathrm{KEPW} \\
\mathrm{KEPW} \\
\mathrm{KEPW} \\
\mathrm{KEPW}\end{array}$ \\
\hline N. malayana & $\begin{array}{l}\text { Johor, Pontian, Sg Benut } \\
\text { Johor, Pontian, Ulu Sanglang } \\
\text { Johor, Pontian, Ulu Benut } \\
\text { Sarawak, Kapit, Ulu Balleh }\end{array}$ & $\begin{array}{l}\text { KEP } 72801 \\
\text { KEP } 69801 \\
\text { KEP } 69954 \\
\text { S } 28431\end{array}$ & $\begin{array}{l}\text { wt6551 wt6704 } \\
\text { wt8232 } \\
-\end{array}$ & $\begin{array}{l}\text { KEPw } \\
\text { KEPW } \\
\text { KEPw } \\
\text { SARFW }\end{array}$ \\
\hline N. glabra & Sarawak, Kuching, Semengoh FR & S 25450 & - & SARFW \\
\hline N. piluliflora & Sarawak, Kuching, Semengoh FR & S 35031 & - & SARFW \\
\hline N. strigosa & Sarawak, Baram, Batang Tinjar & S 15540 & - & SARFW \\
\hline N. synandra & Sarawak, Serian, Bukit Gaharu & $\begin{array}{l}\text { KEP } 74801 \\
\text { KEP } 55734 \\
\text { SAN } 140478\end{array}$ & $\begin{array}{l}\text { wt8225 } \\
\text { wt8224 } \\
\text { wt1470 }\end{array}$ & $\begin{array}{l}\text { KEPw } \\
\text { KEPw } \\
\text { SANw }\end{array}$ \\
\hline
\end{tabular}

Durio, Kostermansia dan Neesia. Antara ciri diagnostik Bombax (Jadual 2) yang dapat memisahkannya daripada Coelostegia, Durio, Kostermansia dan Neesia ialah bukaan pit belahan, kehadiran pit berbirai, kehadiran ruji dua saiz, struktur bertingkat dan kehadiran selaput ruji (Rajah 3(a)3(c)). Manakala ciri diagnostik paling utama Coelostegia, Durio, Kostermansia dan Neesia (Jadual 2) ialah kehadiran sel jubin (Rajah 3(d)). Menurut Metcalfe dan Chalk (1983, 1950) ciri ini merupakan ciri khas yang hanya hadir pada tribus Durioneae dalam Bombacaceae.

Hasil kajian ini selari dengan Judd dan Manchester (1997) yang menggunakan analisis Henning86 iaitu gabungan ciri morfologi, palinologi, kimia, anatomi daun dan kayu menunjukkan kumpulan Durio juga terpisah daripada kumpulan Bombax. Kajian DNA molekul oleh penyelidik terdahulu turut merekodkan Bombax terpisah daripada Coelostegia, Durio, Kostermansia dan Neesia
(Alverson et al. 1999, 1998; Baum et al. 2004, 1998; Nyffeler \& Baum 2001, 2000). Menurut Refaat et al. (2012) kajian fitokimia terhadap Bombacaceae menunjukkan Bombax mempunyai hubungan yang sangat rapat dengan Adansonia L., Ceiba Mill., Chorisia Hassl., Ochroma Sw. dan Pachira Aubl. sebaliknya menunjukkan hubungan yang jauh dengan Durio.

Kumpulan berikutnya ialah yang memisahkan antara kelompok genus di dalam subfamili Helicteroideae (Rajah 1). Berdasarkan fenogram jelas menunjukkan empat genus dalam subfamili Helicteroideae iaitu Helicteres, Mansonia, Reevesia, dan Triplochiton terpisah daripada lima genus subfamili Helicteriodeae yang lain iaitu Coelostegia, Durio, Kostermansia, Neesia dan Cullinea. Mengikut pengelasan tradisi empat genus tersebut berada di bawah Sterculiaceae, tribus Helicterae manakala lima genus lagi adalah di bawah Bombacaceae, tribus Durioneae 
JADUAL 2. Perbandingan ciri fizikal dan mikroskopi anatomi kayu subfamili Bombacoideae dan Helicteroideae

\begin{tabular}{|c|c|c|}
\hline Perincian ciri & Bombacoideae (Bombax) & $\begin{array}{l}\text { Helicteroideae (Coelostegia, Durio, } \\
\text { Kostermansia, Neesia) }\end{array}$ \\
\hline \multicolumn{3}{|l|}{ Fizikal } \\
\hline Ketumpatan & Ringan & $\begin{array}{l}\text { Ringan ke sederhana berat, sederhana berat } \\
\text { ke berat dan berat }\end{array}$ \\
\hline Tanda riak & Hadir & Tidak hadir \\
\hline \multicolumn{3}{|l|}{ Mikroskopi anatomi kayu } \\
\hline Kumpulan sel salur (\%) & $92 \%$ tunggala & $55-56 \%$ tunggalb \\
\hline Kepadatan sel salur per mm2 & $2 b(1-3)$ & $4 a(3-5)$ \\
\hline Panjang unsur sel salur $(\mu \mathrm{m})$ & $472 b(422-523)$ & $703 a(479-886)$ \\
\hline $\begin{array}{l}\text { Bentuk dan bukaan pit antara } \\
\text { vaskular }\end{array}$ & $\begin{array}{l}\text { Bentuk pit poligonal dan bukaan pit belahan } \\
\text { (slit-like) }\end{array}$ & $\begin{array}{l}\text { Bentuk pit poligonal, elips, bujur dan bukaan } \\
\text { pit bulat, elips dan bujur }\end{array}$ \\
\hline Kehadiran pit berbirai & Hadir & Tidak hadir \\
\hline Saiz pit antara vaskular & Besar & Sangat kecil, kecil, sederhana \\
\hline $\begin{array}{l}\text { Saiz, bentuk dan bukaan pit } \\
\text { salur-ruji }\end{array}$ & $\begin{array}{l}\text { Sempadan yang kurang, ringkas, bentuk dan } \\
\text { bukaan pit melintang bujur (gash-like) dan bulat, } \\
\text { saiz besar }\end{array}$ & $\begin{array}{l}\text { Sempadan yang jelas, bentuk dan bukaan pit } \\
\text { bulat, bujur dan elips, saiz sangat kecil ke } \\
\text { sederhana }\end{array}$ \\
\hline Ketebalan sel serabut & Nipis & Nipis ke tebal \\
\hline Panjang sel serabut $(\mu \mathrm{m})$ & $2276 a(2073-2480)$ & $1659 b(1342-1966)$ \\
\hline $\begin{array}{l}\text { Bilangan sel per jalur } \\
\text { parenkima }\end{array}$ & $4 \mathrm{~b}(3-5)$ & $7 \mathrm{a}(6-8)$ \\
\hline Kehadiran ruji dua saiz & $\begin{array}{l}\text { Hadir, ruji kecil terdiri dari 1-3 sel lebar, rendah, } \\
\text { ruji besar terdiri daripada 4-6 sel lebar dan tinggi }\end{array}$ & $\begin{array}{l}\text { Tidak hadir, ruji uniseriat dan multiseriat 3-8 } \\
\text { sel }\end{array}$ \\
\hline $\begin{array}{l}\text { Ketinggian ruji multiseriat } \\
(\mu \mathrm{m})\end{array}$ & 3270a (2577-3965) & $1522 b(942-2369)$ \\
\hline Kehadiran selaput ruji & Hadir, menyelaputi sebahagian daripada ruji & Tidak hadir \\
\hline Kehadiran sel jubin & Tidak hadir & Hadir, jenis Durio \\
\hline Struktur bertingkat & $\begin{array}{l}\text { Hadir, ruji rendah bertingkat, ruji tinggi tidak } \\
\text { bertingkat,parenkima aksial dan sel serabut } \\
\text { bertingkat }\end{array}$ & Tidak hadir \\
\hline Hablur rombus & $\mathrm{C}, \mathrm{NC}, \mathrm{R}$ & $\mathrm{C}, \mathrm{NC}, \mathrm{TC}$ \\
\hline Silika & Tidak hadir & $\begin{array}{l}\text { Hadir pada sesetengah spesies kebiasaannya } \\
\text { pada parenkima aksial, kadangkala hadir } \\
\text { pada sel jubin, sel prokumben dan sel } \\
\text { menegak/sel segiempat sama }\end{array}$ \\
\hline
\end{tabular}

(Hutchinson 1967). Fenogram hasil kajian ini selari dengan fenogram yang dihasilkan oleh Judd dan Manchester (1997) yang menggunakan gabungan ciri morfologi, palinologi, kimia, anatomi daun dan kayu yang juga menunjukkan Durio terpisah daripada Reevesia dan Helicteres.

Hasil kajian Bayer et al. (1999) menunjukkan Helicteres, Mansonia, Reevesia, Triplochiton, Coelostegia, Durio, Kostermansia, Neesia dan Cullinea diletakkan di bawah subfamili yang sama iaitu subfamili Helicteroideae. Bayer dan Kubitzki (2003) juga meletakkan kesemua genus ini di bawah subfamili Helicteroideae tetapi terdapat dua kelompok iaitu kelompok yang dikenali sebagai Helicteroideae s.s. (Helicteres, Mansonia, Neoregnellia, Reevesia, Triplochiton dan Ungeria) dan Helicteroideae: Durioneae (Coelostegia, Durio, Kostermansia, Neesia,
Boschia dan Cullinea). Pemisahan tidak dilakukan terhadap kedua-dua kelompok ini kerana berdasarkan data DNA molekul, genus dalam kelompok Helicteroideae s.s. adalah berhubung kait dengan genus dalam kelompok Helicteroideae: Durioneae (Bayer \& Kubitzki 2003; Bayer et al. 1999). Alverson et al. (1999) dan Nyffeler dan Baum (2000) juga menyatakan genus dalam kelompok Helicteroideae s.s. dan genus dalam kelompok Helicteroideae: Durioneae adalah berkait rapat.

Analisis fenetik berangka kajian ini (Rajah 1), jelas menunjukkan terdapat pemisahan antara dua kelompok di dalam famili Helicteroideae kerana perbezaan yang signifikan pada ciri fizikal dan mikroskopi anatomi kayu (Jadual 3) di antara genus dalam kelompok Helicteroideae s.s. dan juga genus dalam kelompok Helicteroideae: Durioneae. Oleh itu, hasil kajian ini mencadangkan 


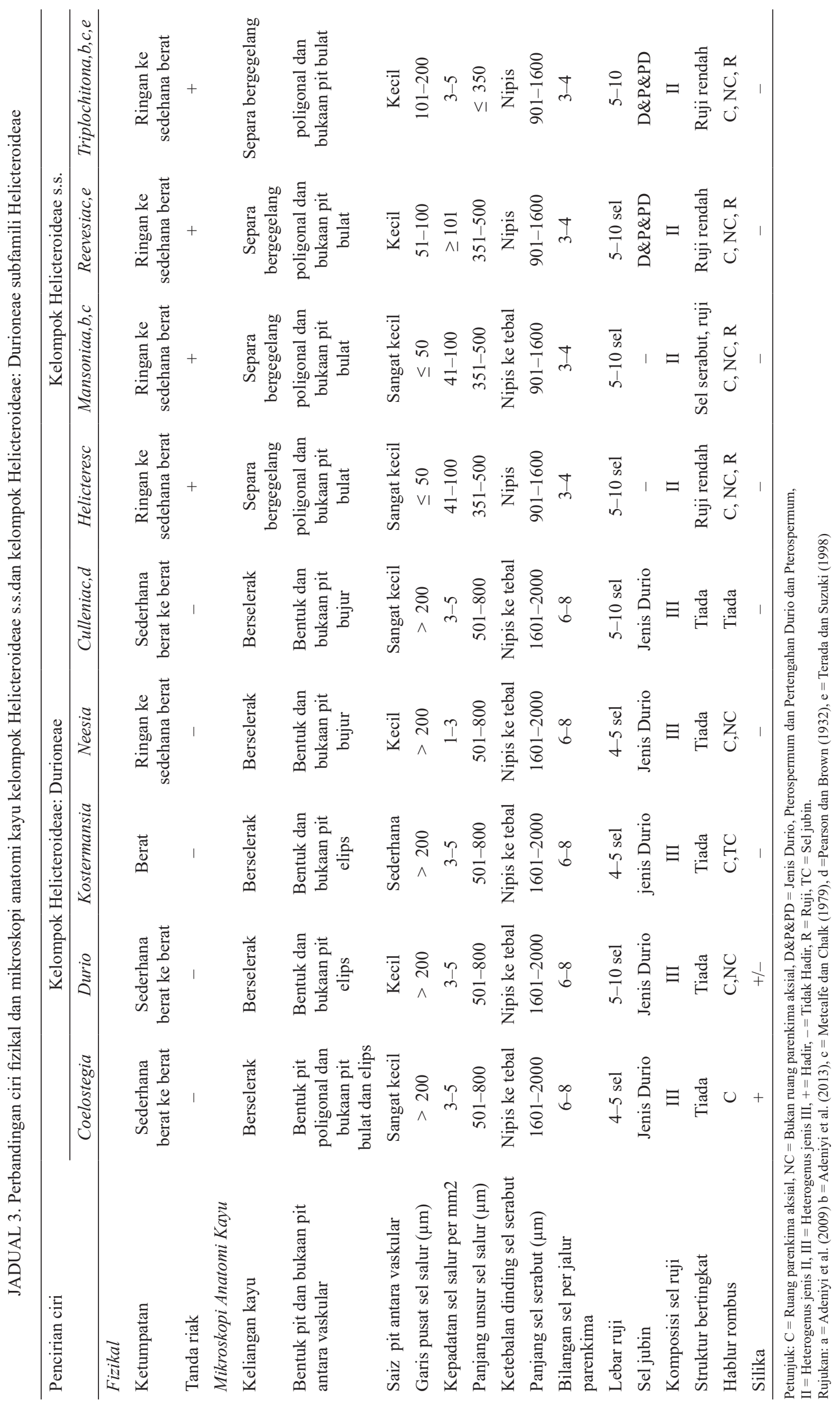


JADUAL 4. Perbandingan ciri fizikal dan mikroskopi anatomi kayu genus Coelostegia, Durio, Kostermansia dan Neesia

\begin{tabular}{|c|c|c|c|c|}
\hline Perincian ciri & Coelostegia & Durio & Kostermansia & Neesia \\
\hline \multicolumn{5}{|l|}{ Fizikal } \\
\hline Ketumpatan & Sederhana berat ke berat & Sederhana berat ke berat & Berat & $\begin{array}{l}\text { Ringan ke } \\
\text { sederhana berat }\end{array}$ \\
\hline \multicolumn{5}{|l|}{$\begin{array}{l}\text { Mikroskopi Anatomi } \\
\text { Kayu }\end{array}$} \\
\hline Susunan sel salur & Berjejari & Berjejari & Berjejari dan membujur & Berjejari \\
\hline $\begin{array}{l}\text { Bentuk dan bukaan } \\
\text { pit antara vaskular }\end{array}$ & $\begin{array}{l}\text { Bentuk pit poligonal dan } \\
\text { bukaan pit bulat dan elips }\end{array}$ & $\begin{array}{l}\text { Bentuk dan bukaan pit } \\
\text { elips }\end{array}$ & $\begin{array}{l}\text { Bentuk dan bukaan pit } \\
\text { elips }\end{array}$ & $\begin{array}{l}\text { Bentuk dan } \\
\text { bukaan pit bujur }\end{array}$ \\
\hline $\begin{array}{l}\text { Saiz pit antara } \\
\text { vaskular }\end{array}$ & Sangat kecil & Kecil & Sederhana & Kecil \\
\hline $\begin{array}{l}\text { Saiz, bentuk dan } \\
\text { bukaan pit salur-ruji }\end{array}$ & $\begin{array}{l}\text { Bentuk dan bukaan bulat, saiz } \\
\text { sangat kecil }\end{array}$ & $\begin{array}{l}\text { Bentuk dan bukaan } \\
\text { elips, saiz kecil }\end{array}$ & $\begin{array}{l}\text { Bentuk dan bukaan } \\
\text { elips, saiz sederhana }\end{array}$ & $\begin{array}{l}\text { Bentuk dan } \\
\text { bukaan bujur, } \\
\text { saiz kecil }\end{array}$ \\
\hline $\begin{array}{l}\text { Kepadatan sel salur } \\
\text { per } \mathrm{mm} 2\end{array}$ & $4 a(3-5)$ & $4 a(3-5)$ & $4 a(3-5)$ & $2 \mathrm{~b}(1-3)$ \\
\hline $\begin{array}{l}\text { Ketinggian ruji } \\
\text { multiseriat }(\mu \mathrm{m})\end{array}$ & 1470c (1023-1918) & $1808 \mathrm{a}(1248-2369)$ & 1206d (942-1471) & $\begin{array}{l}1602 b(1274- \\
1930)\end{array}$ \\
\hline Lebar ruji multiseriat & $4 b(4-5)$ & $6 a(6-8)$ & $4 b(4-5)$ & $4 b(4-5)$ \\
\hline $\begin{array}{l}\text { Kehadiran hablur } \\
\text { rombus }\end{array}$ & $\begin{array}{l}\text { Hadir pada ruang parenkima } \\
\text { aksial }\end{array}$ & $\begin{array}{l}\text { Hadir pada sesetengah } \\
\text { spesies pada ruang dan } \\
\text { bukan ruang parenkima } \\
\text { aksial }\end{array}$ & $\begin{array}{l}\text { Hadir pada ruang } \\
\text { parenkima aksial dan } \\
\text { sel jubin }\end{array}$ & $\begin{array}{l}\text { Hadir pada } \\
\text { ruang dan bukan } \\
\text { ruang parenkima } \\
\text { aksial }\end{array}$ \\
\hline Taburan silika & $\begin{array}{l}\text { Hadir pada parenkima aksial } \\
\text { sahaja, tetapi bagi C. montana } \\
\text { terdapat pada parenkima aksial, } \\
\text { sel prokumben, sel menegak/ } \\
\text { segiempat sama, kadangkala } \\
\text { pada sel jubin }\end{array}$ & $\begin{array}{l}\text { Hadir pada sesetengah } \\
\text { spesies, kebiasaanya } \\
\text { pada parenkima aksial, } \\
\text { kadangkala hadir } \\
\text { pada sel jubin dan sel } \\
\text { prokumben }\end{array}$ & Tidak hadir & Tidak hadir \\
\hline Saiz silika & Saiz kecil, sederhana, besar & Saiz sederhana & Tidak hadir & Tidak hadir \\
\hline Bentuk silika & Bentuk oblong dan agregat & Bentuk globular & Tidak hadir & Tidak hadir \\
\hline $\begin{array}{l}\text { Jenis permukaan } \\
\text { silika }\end{array}$ & Permukaan granul & Permukaan licin & Tidak hadir & Tidak hadir \\
\hline
\end{tabular}

Min diikuti dengan huruf yang sama pada baris yang sama adalah tiada perbezaan signifikan pada $p \leq 0.05$. Nilai pada kurungan adalah julat

kelompok Helicteroideae: Durioneae dikeluarkan daripada subfamili Helicteroideae dan meletakkannya di dalam subfamili baharu iaitu Durionoideae yang terdiri daripada Coelostegia, Durio, Kostermansia, Neesia dan Cullinea. Kajian ini juga mencadangkan kelompok Helicteroideae s.s. dikekalkan sebagai subfamili Helicteroideae yang terdiri daripada Helicteres, Mansonia, Neoregnellia, Reevesia, Triplochiton dan Ungeria. Cheek $(2007,2006)$ juga tidak bersetuju untuk meletakkan kelompok Helicteroideae: Durioneae bersama kelompok Helicteroideae s.s. di bawah satu subfamili dan telah menaikkan taraf kelompok Helicteroideae: Durioneae kepada famili Durionaceae.

Hasil kajian ini menyokong cadangan pengelasan pada peringkat subfamili oleh Bayer dan Kubitzki (2003) dan Bayer et al. (1999) yang berasaskan DNA tetapi menolak cadangan pengelasan Cheek yang menaikkan taraf subfamili Bombacoideae kepada famili Bombacaceae, subfamili Helicteroideae s.s. kepada Helicteradaceae dan subfamili Helicteroideae: Durioneae kepada famili Durionaceae berdasarkan gabungan ciri morfologi, palinologi, anatomi daun dan kayu serta data DNA daripada kajian terdahulu (Cheek 2007, 2006). Berdasarkan analisis fenetik berangka kajian ini (Rajah 1) menunjukkan persamaan ciri adalah tinggi dengan indeks persamaan ciri Bombax (subfamili Bombacoideae) dan genus lain dalam subfamili Helicteroideae dengan 68.2\%. Manakala indeks persamaan ciri kelompok Helicteroideae s.s. dan kelompok Helicteroideae: Durioneae adalah 71.8\% (Rajah 1). Ini menunjukkan indeks persamaan ciri adalah tinggi iaitu melebihi 50\% persamaan. Oleh itu, mengukuhkan lagi kajian ini untuk menyokong pengelasan kepada peringkat 


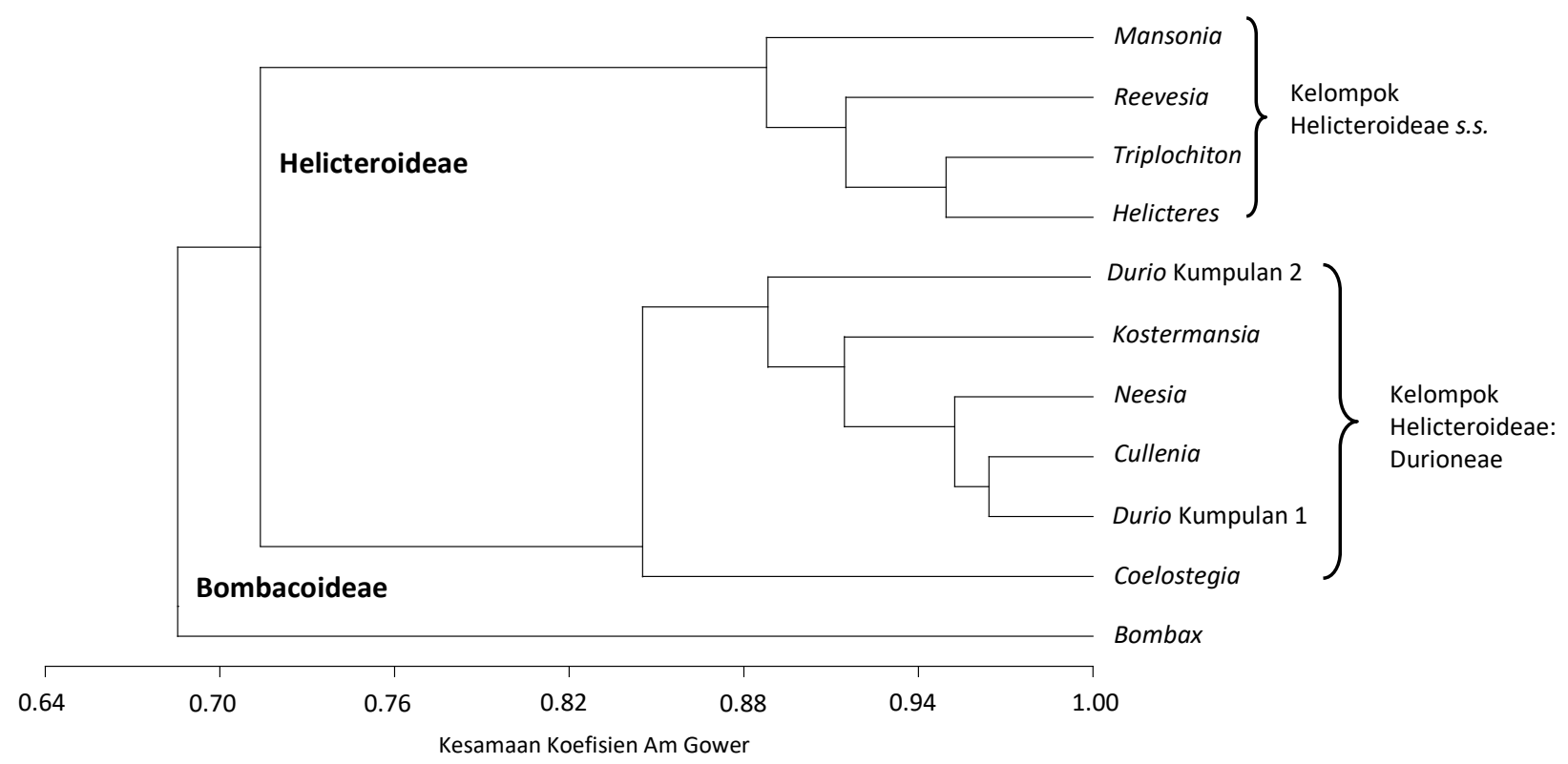

RAJAH 1. Fenogram daripada analisis kluster UPGMA terhadap 10 genus kajian dengan menggunakan gabungan ciri fizikal dan mikroskopik anatomi kayu

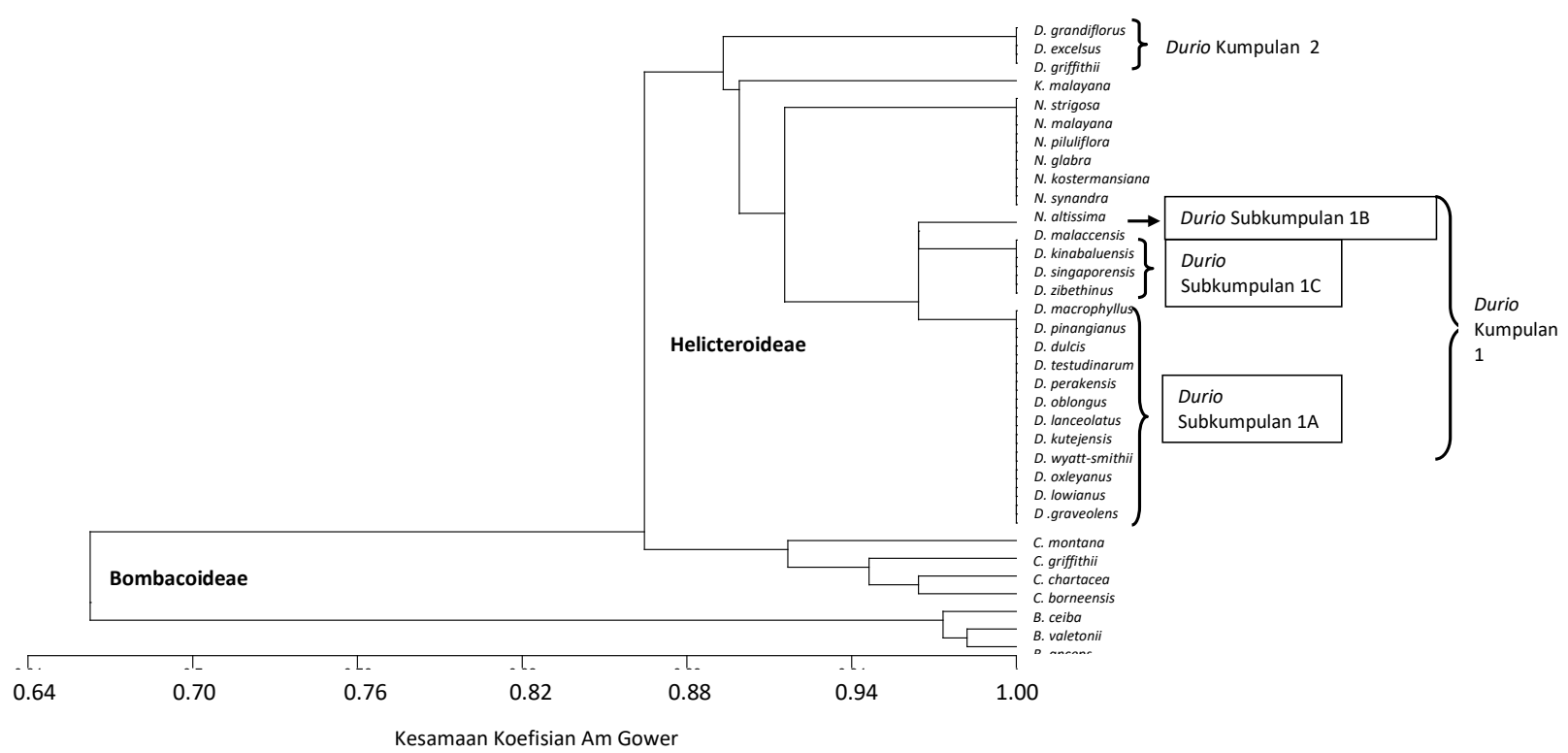

RAJAH 2. Fenogram daripada analisis kluster UPGMA terhadap tiga spesies subfamili Bombacoideae dan 33 spesies subfamili Helicteroideae dengan menggunakan gabungan ciri fizikal dan mikroskopik anatomi kayu

subfamili oleh Bayer dan Kubitzki (2003) dan Bayer et al. (1999) tetapi menolak cadangan pengelasan kepada peringkat famili oleh Cheek $(2007,2006)$.

\section{PENGELOMPOKAN DALAM ANALISIS FENETIK BERANGKA PERINGKAT GENUS DAN SPESIES}

Berdasarkan fenogram yang dihasilkan daripada analisis fenetik berangka (Rajah 1) jelas menunjukkan ciri fizikal dan mikroskopi anatomi kayu (Jadual 4) dapat memisahkan keempat-empat genus dalam subfamili Helicteroideae: Durioneae iaitu Coelostegia, Durio, Kostermansia dan
Neesia. Fenogram (Rajah 2) yang dihasilkan berdasarkan ciri fizikal dan mikroskopi anatomi kayu (Jadual 5) juga dapat memisahkan sehingga ke peringkat spesies pada genus Bombax, Coelostegia dan satu spesies pada genus Durio (D. malaccensis) serta terdapat pemisahan yang hanya berlaku pada peringkat kumpulan spesies pada genus Durio, tetapi tiada pemisahan peringkat spesies pada genus Neesia (Rajah 2).

Fenogram (Rajah 2) menunjukkan terdapat pembentukan dua kumpulan dalam genus Bombax. Bombax ceiba Burm.f. terpisah daripada spesies yang lain 

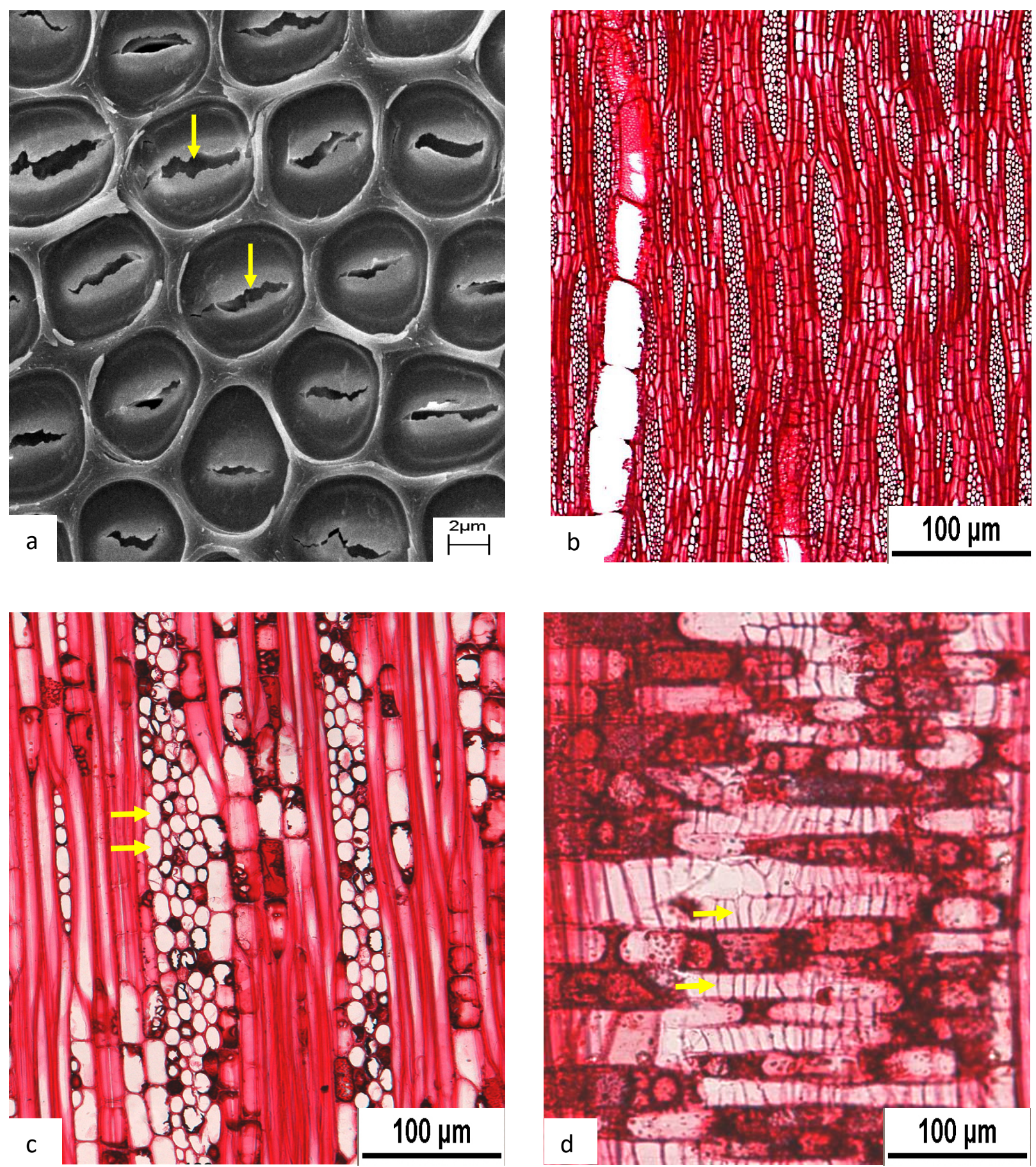

RAJAH 3. Ciri mikroskopik anatomi kayu di bawah mikroskop imbasan elektron (a), di bawah mikroskop cahaya (b-d). a) Bukaan pit belahan, pit berbirai (anak panah), b) Ruji dua saiz dan struktur bertingkat, c) selaput ruji (anak panah), d) sel jubin (anak panah). a) B. anceps, b\&c) B. valetonii, d) D. griffithii

hanya dengan satu ciri iaitu komposisi sel ruji jenis heterogenus II (sel prokumben dan dua baris sel menegak/ segiempat sama) manakala $B$. anceps Pierre dan B.valetonii Hochr. mempunyai komposisi sel ruji jenis heterogenus III (prokumben dan satu baris sel menegak/segiempat sama). B. anceps dan B. valetonii berkongsi indeks persamaan tetapi masih dapat dipisahkan dengan hanya berbeza berdasarkan kedudukan hablur rombus. B. anceps menunjukkan hablur rombus hadir pada sel ruji menegak/ segiempat sama dan parenkima aksial, manakala $B$. valetonii menunjukkan hablur rombus hanya hadir pada parenkima aksial (Jadual 5).

Bagi genus Coelostegia terdapat tiga kumpulan terbentuk yang terpisah berdasarkan tiga ciri iaitu kedudukan taburan silika, saiz dan bentuk silika (Jadual 5). Berdasarkan fenogram (Rajah 2), C. montana Sidiyasa terpisah jauh daripada tiga spesies Coelostegia yang lain kerana mempunyai taburan silika, saiz dan bentuk silika yang berbeza. Taburan silika bagi C. montana ialah pada parenkima aksial, sel jubin, sel prokumben dan sel 


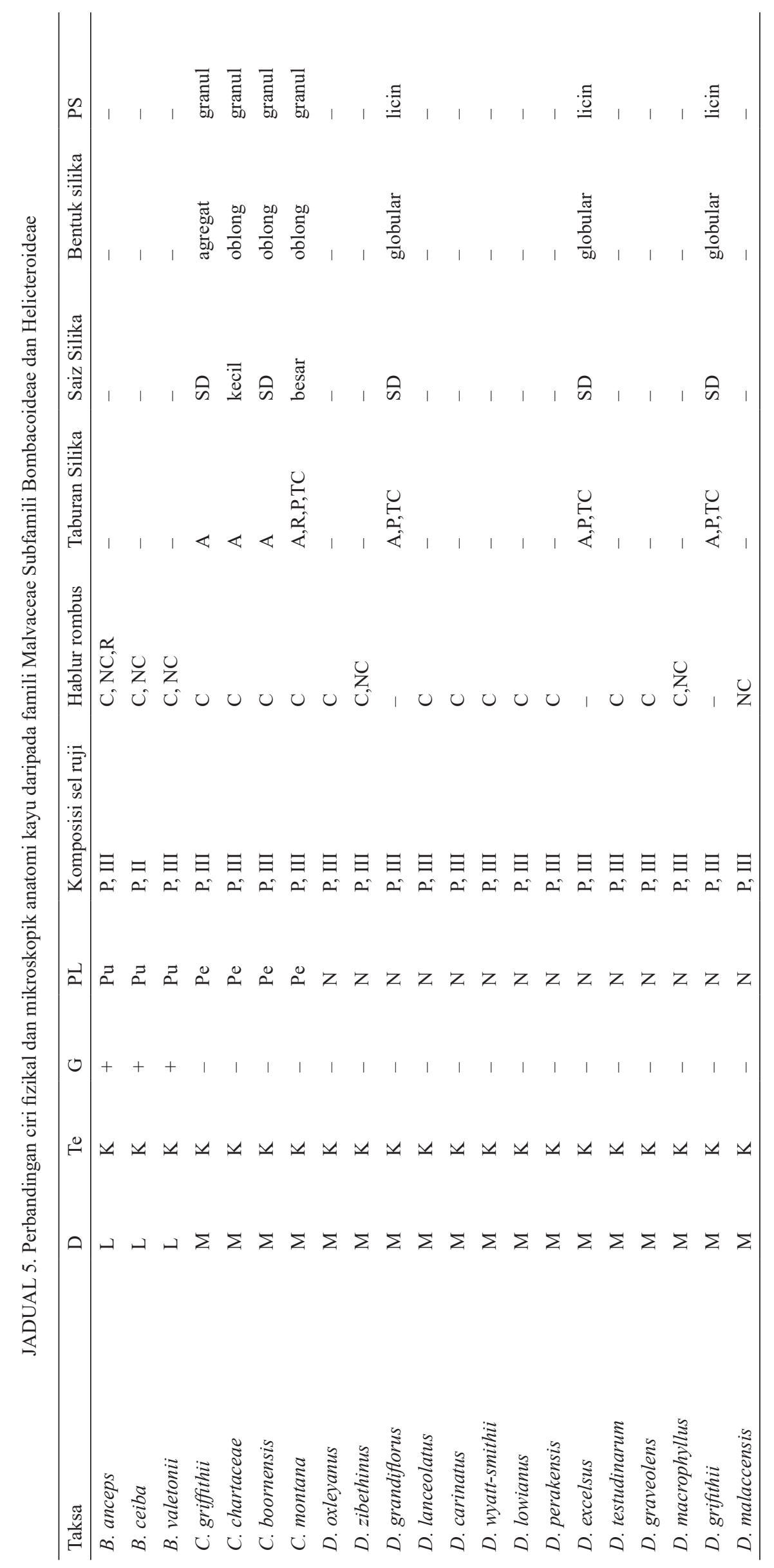




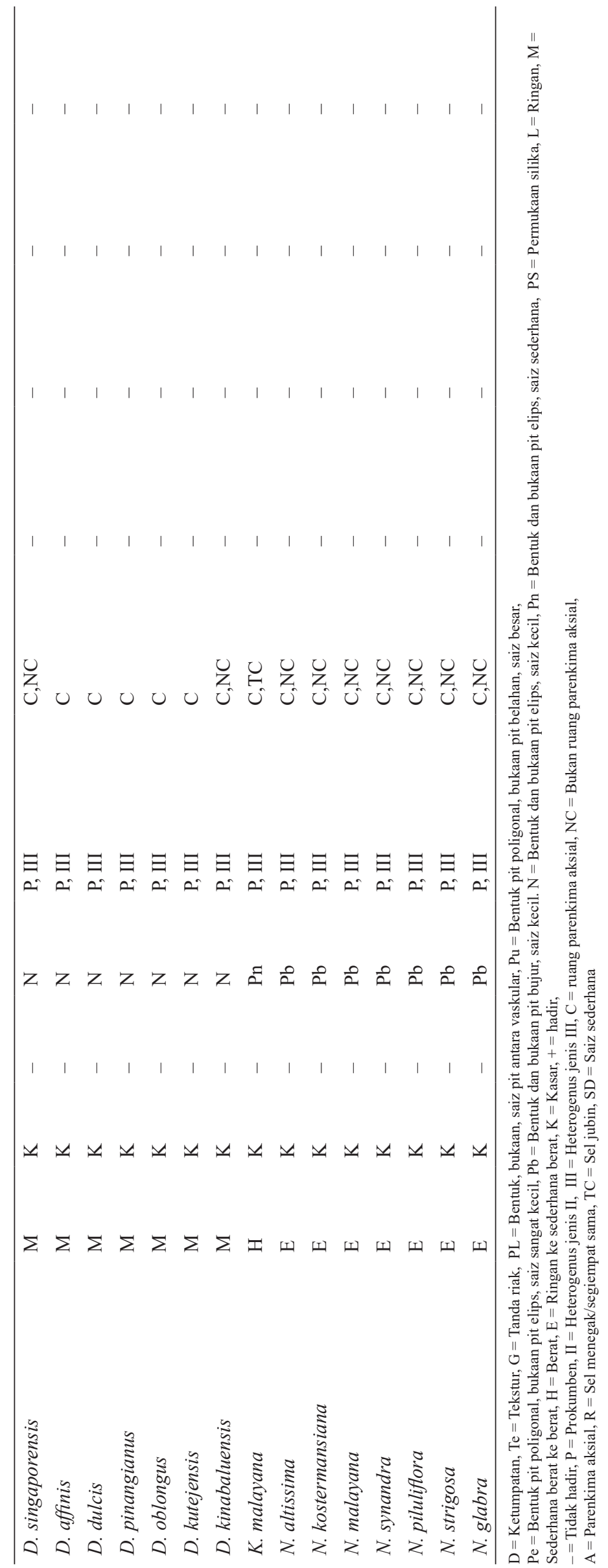



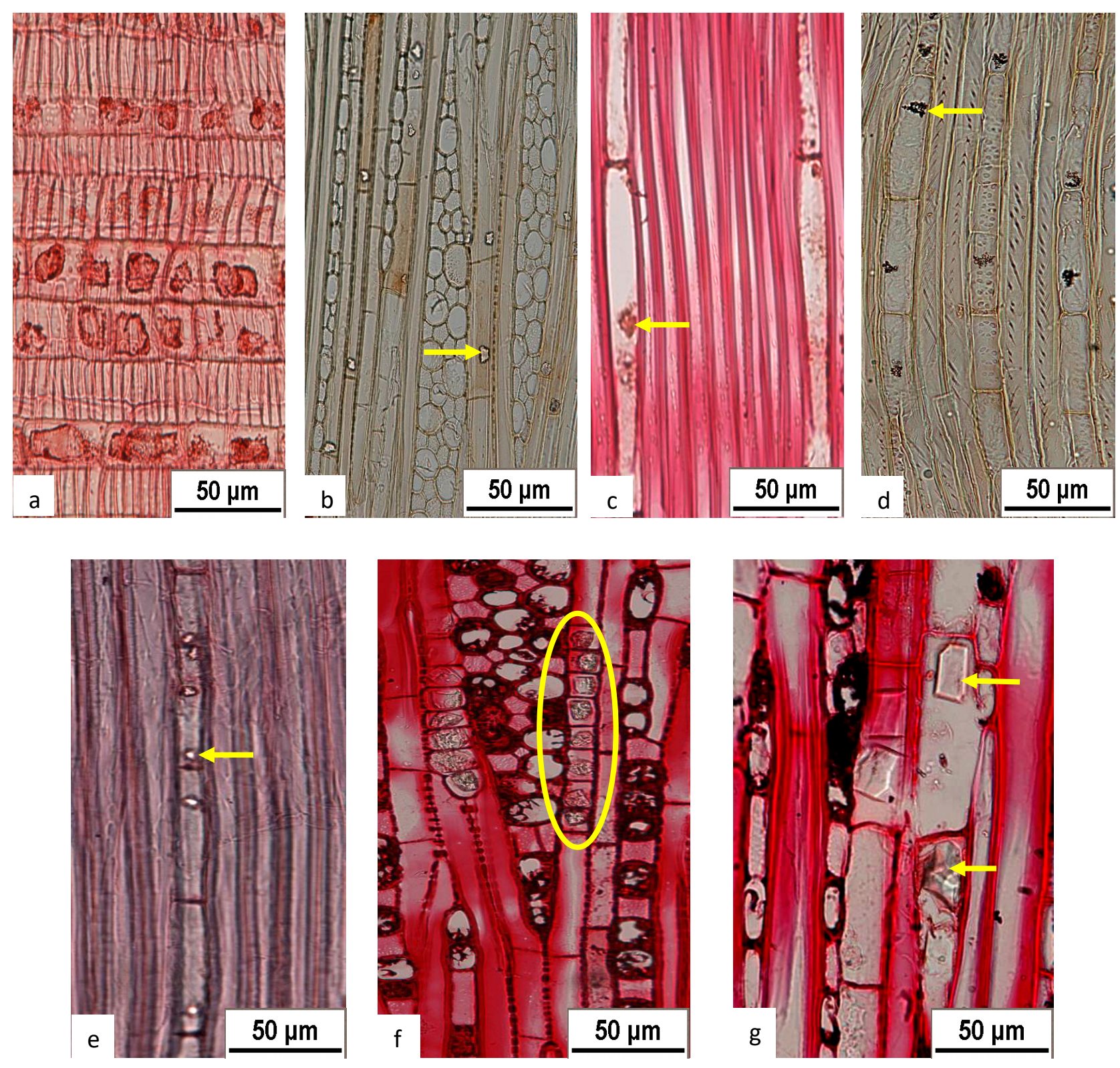

RAJAH 4. Ciri mikroskopi anatomi kayu di bawah mikroskop cahaya (a-g), a) Taburan silika di sel jubin, sel prokumben dan sel menegak/segiempat sama, b-e) Taburan silika di parenkima aksial (anak panah), f) hablur rombus di ruang parenkima aksial (bulatan), g) hablur rombus di bukan ruang parenkima aksial (anak panah). a) C. montana, b) C. borneensis, c) C. chartaceae, d) C. griffithii, e) D. excelsus, f) D. lowianus dan g) D. malaccensis

menegak/segiempat sama (Rajah 4(a)), manakala $C$. borneensis Becc., C. chartaceae Soegeng dan C. griffithii Benth. taburan silikanya ialah pada parenkima aksial (Rajah 4(b)-(d)). Coelostegia griffithii pula dapat dibezakan daripada spesies Coelostegia yang lain melalui bentuk silikanya jenis agregat. Spesies Coleostegia yang lain bentuk silikanya oblong (Jadual 5). Fenogram (Rajah 2) menunjukkan $C$. borneensis dan C. chartacea berkongsi indeks persamaan tetapi masih dapat dipisahkan berdasarkan saiz silika dengan $C$. borneensis saiz silikanya sederhana manakala $C$. chartaceae saiz silikanya kecil (Jadual 5). Berdasarkan kajian oleh Noraini et al. (2008) juga telah membuktikan bahawa spesies dalam genus
Coelostegia dapat dibezakan dan dipisahkan berdasarkan ciri anatomi daun.

Bagi Durio terdapat dua kumpulan utama yang terpisah berdasarkan kehadiran silika dan hablur rombus (Rajah 2). Bagi Kumpulan 1 kesemua spesies dicirikan dengan kehadiran hablur rombus tetapi tiada kehadiran silika. Kumpulan ini terbahagi kepada tiga subkumpulan iaitu Durio Subkumpulan 1A, 1B dan 1C dengan subkumpulan ini terpisah berdasarkan kedudukan hablur rombus. Durio Subkumpulan 1A dicirikan dengan hablur rombus hadir pada ruang parenkima aksial sahaja (Rajah 4(f)), Durio Subkumpulan 1(B) dicirikan dengan hablur rombus hanya hadir pada bukan ruang parenkima aksial 
sahaja (Rajah 4(g)) dan Durio Subkumpulan 1C hablur rombus hadir pada kedua-dua ruang dan bukan ruang parenkima aksial (Jadual 5).

Terdapat perbezaan pada Durio Kumpulan 2 (Rajah 2) dengan D. excelsus Bakh., D. grandiflorus Mast. dan D. griffithii (Mast.) Bakh. ini dahulunya adalah genus Boschia (Master 1874). Kemudian Boschia disatukan dengan Durio oleh Bakhuzen van den Brink (1924) dan disokong oleh Kostermans (1958). Berdasarkan kajian DNA oleh Bayer et al. (1999) dan Bayer dan Kubitzki (2003) pula telah meletakkan genus Boschia sebagai genus tersendiri. Durio Kumpulan 2 (D. excelsus, D. grandiflorus dan D. griffithii) dicirikan dengan kehadiran silika bentuk globular pada parenkima aksial (Rajah 4(e)) tetapi tiada kehadiran hablur rombus. Ciri ini telah menyebabkan Durio Kumpulan 2 terpisah daripada kumpulan Durio yang lain. Namun begitu, walaupun berdasarkan analisis fenetik berangka, terdapat pemisahan antara $D$. excelsus, $D$. grandiflorus dan D. griffithii dengan spesies Durio yang lain tetapi kajian ini tetap menyokong cadangan penyelidik terdahulu iaitu Ashton (1988), Bakhuizen van den Brink (1924), Kochummen (1972), Kostermans (1958) dan Salma (2011). Mereka mencadangkan Boschia disatukan dengan Durio kerana dengan ciri tunggal anter dehisen adalah tidak mencukupi untuk genus ini dijadikan sebagai genus tersendiri. Hasil kajian ini juga tidak menyokong pemisahan D. excelsus, D. grandiflorus dan D. griffithii daripada genus Durio kerana hanya dengan satu ciri iaitu kehadiran silika adalah tidak mencukupi untuk menaik taraf kepada genus Boschia sebaliknya menyokong tiga spesies ini disatukan dengan Durio.

Fenogram (Rajah 2) menunjukkan Cullenia berkongsi indeks persamaan dengan Durio tetapi masih boleh dipisahkan. Pemisahan adalah berdasarkan ciri bentuk pit antara vaskular Cullenia yang berbentuk bujur berbanding Durio yang bentuk pitnya ialah elips. Saiz pit antara vaskular Cullenia yang dikategorikan sebagai sangat kecil berbanding Durio yang dikategorikan sebagai kecil. Selain itu, pada Cullenia tiada kehadiran hablur direkodkan (Jadual 3). Kostermansia malayana (Rajah 2) jelas terpisah daripada spesies yang lain. Ini menunjukkan terdapat perbezaan ciri fizikal dan mikroskopi anatomi kayu yang signifikan antara $K$. malayana dengan spesies lain dalam subfamili Helicteroideae: Durioneae (Jadual 5). Manakala tidak berlaku pemisahan antara spesies bagi genus Neesia (Rajah 2), ini menunjukkan tiada perbezaan ciri fizikal dan mikroskopi anatomi kayu yang signifikan antara spesies bagi genus Neesia (Jadual 5).

\section{KESIMPULAN}

Hasil analisis fenetik berangka kajian ini jelas menyokong cadangan pengelasan Bayer dan Kubitzki (2003) dan Bayer et al. (1999) yang memisahkan Bombax daripada Coelostegia, Durio, Kostermansia dan Neesia dan diletakkan di bawah subfamili yang berbeza iaitu masingmasing di bawah Bombacoideae and Helicteroideae. Berdasarkan analisis fenetik berangka, kumpulan
Helicteroideae: Durioneae (Coelostegia, Durio, Kostermansia dan Neesia) dicadangkan untuk dikeluarkan daripada subfamili Helicteroideae dan diletakkan di bawah subfamili baharu iaitu Durionoideae. Selain itu, kajian ini juga menolak konsep pengelasan Cheek $(2007,2006)$ yang menaik taraf subfamili kepada peringkat famili sebaliknya menyokong cadangan pengelasan kepada peringkat subfamili oleh Bayer dan Kubitzki (2003) dan Bayer et al. (1999). Berdasarkan kajian ini, menunjukkan genus Boschia perlu disatukan dengan Durio.

\section{RUJUKAN}

Adeniyi, I.M., Adebagbo, C.A., Oladapo, F.M. \& Ayetan, G. 2013. Utilisation of some selected wood species in relation to their anatomical features. Global Journal of Science Frontier Research Agriculture and Veterinary 13(9): 22494626.

Adeniyi, A.K., Aworinde, D.O. \& Folorunso, A.E. 2009. Use of wood characters in the identification of selected timber species in Nigeria. Notulae Botanicae Horti Agrobotanici 37(2): 28-32.

Alverson, W.S., Whitlock, B.A., Nyffeler, R., Bayer, C. \& Baum, D.A. 1999. Phylogeny of the core Malvales: Evidence from $n d h \mathrm{~F}$ sequence data. American Journal of Botany 86(10): 1474-1486.

Alverson, W.S., Karol, K.G., Baum, D.A., Chase, M.W., Swensen, S.M., McCourt, R. \& Systema, K.J. 1998. Circumscription of the Malvales and relationships to other Rosidae: Evidence from $r b c \mathrm{~L}$ sequence data. American Journal of Botany 85(6): 876-887.

Ashton, P.S. 1988. Manual of the Non-Dipterocarp Trees of Sarawak. Jil. 2. Kuching: Dewan Bahasa dan Pustaka, Sarawak Branch.

Bakhuizen van den Brink, R.C. 1924. Revisio Bombacacearum Bulletin Jardin Botanique de Buitenzorg 6(2): 161-240.

Baum, D.A., Smith, S.D., Yen, A., Alverson, W.S., Nyffeler, R., Barbara, A.W. \& Rebecca, L.O. 2004. Phylogetic relationship of Malvatheca (Bombacoideae and Malvoideae: Malvaceae (sensu lato) as inferred from plastid DNA sequences. American Journal of Botany 91(11): 1863-1871.

Baum, D.A., Alverson, W.S. \& Nyffeler, R. 1998. A durian by any other name: Taxonomy and nomenclature of the core Malvales. Harvard Papers of Botany 3(2): 315-330.

Bayer, C. \& Kubitzki, K. 2003. Malvaceae. Dlm. The Families and Genera of Vascular Plants. Flowering Plants Dicotyledons: Malvales, Capparales and Non-betalain Caryophyllales, Jilid. 5, disunting oleh Kubitzki, K. \& Bayer, C. New York: Springer-Verlag. hlm. 225-311.

Bayer, C., Michael, F.F., De Bruijn, A.Y., Vincent, S., Cynthia, M.M., Kubitzki, K., William, S.A. \& Mark, W.C. 1999. Support for an expended family concept of Malvaceae within recircumscribed order Malvales: A combined analysis of plastid $a t p \mathrm{~B}$ and $r b c \mathrm{~L}$ DNA sequences. The Botanical Journal of Linnean Society 129(4): 267-303.

Cheek, M. 2006. The validation of two new family names in Malvales: Durionaceae and Browlowiaceae. Kew Bulletin 61: 443.

Cheek, M. 2007. Bombacaceae. Dlm. Flowering Plant Families of the World, disunting oleh Heywood, V.H., Moore, D.M., Richardson, I.B.K. \& Stearn, W.T. New York: SpringerVerlag. hlm. 89-95. 
Duncan, T. \& Baum, B.R. 1981. Numerical phenetics: Its uses in botanical systematics. Annual Review of Ecology and Systematics 12: 387-404.

Herendeen, P.S. \& Miller, R.B. 2000. Utility of wood anatomy characters in cladistic analyses. IAWA Journal (21)3: $247-$ 276.

Hutchinson, J. 1967. The Genera of Flowering Plants: Dicotyledons. Edisi ke-2. Oxford: Clarendon Press. hlm. 468-523.

Jansen, S., Piesschaert, F. \& Smets, E. 2000. Wood anatomy of Elaeagnaceae, with comments on vestured pits, helical thickenings, and systematics relationship. American Journal of Botany 87(1): 20-28.

Jansen, S., Kitin, P., De Pauw, H., Idris, M., Beeckman, H. \& Smets, E. 1998. Preparation of wood specimens for transmitted light microscopy and scanning electron microscopy. Belgium Journal of Botany 131(1): 41-49.

Johnson, R.W. 1982. Effect of weighting and the size of the attribute set in numerical classification. Australian Journal of Botany 30(2): 161-174.

Judd, W.S. \& Manchester, S.R. 1997. Circumscription of Malvaceae (Malvales) as determined by a preliminary cladistic analysis of morphological, anatomical, palynological and chemical characters. Brittonia 49(3): 384-405.

Kochummen, K.M. 1972. Bombacaceae. Dlm. Tree Flora of Malaya: A Manual for Foresters, edited by Whitmore, T.C. Jil. 1. Malayan Forest Records No 26. Kepong: Forest Research Institute Malaysia. hlm. 100-120.

Kostermans, A.J.G.H. 1958. A Monograph of the Genus Durio Adans. (Bombacaceae)-Part II: Species of Burma, Malaya and Sumatra, Additional note on Cullenia ceylanica K. Schum. Communication Forest Research Institute Indonesia No 62. hlm. 1-36.

Masters, M.T. 1874. Durio. Dlm. Flora of British India, disunting Hooker, J.D. Jilid.1. London: L. Reeve. hlm. 348353.

Meeuse, A.D.J. 1982. Cladistics, wood anatomy and angiosperm phylogeny-A challenge. Acta Botany 31(5/6): 345-354.

Menon, P.K.B. 1971. The Anatomy and Identification of Malaysian Hardwoods. Malayan Forest Records No 27. Kepong: Forest Research Institute Malaysia.

Metcalfe, C.R. \& Chalk, L. 1983. Anatomy of the Dicotyledons: Wood Structure and Conclusion of the General Introduction. Jilid. 2. London: Oxford University Press.

Metcalfe, C.R. \& Chalk, L. 1979. Anatomy of the Dicotyledons: Leaves, Stem and Wood in Relation to Taxonomy with Notes on Economic Uses. Jilid 2. London: Oxford University Press.

Metcalfe, C.R. \& Chalk, L. 1950. Anatomy of the Dicotyledons: Leaves, Stem and Wood in Relation to Taxonomy with Notes on Economic Uses. Jilid 1. London: Oxford University Press.

Nair, M.N.B. 1998. Wood Anatomy and Major Uses of Wood. Serdang: Fakulti Perhutanan, Universiti Putra Malaysia.

Noraini, T., Solihani, N.S., Khatijah, H. \& Chung, R.C.K. 2008. Comparative petiole and midrib anatomical characters in selected species of Coelostegia (Bombacaceae) in Malaysia. Proceeding of the 3rd Regional Symposium on Environment and Natural Resources. hlm.712-716.

Nyffeler, R. \& Baum, D.A. 2001. Systematics and character evolution in Durio s.lat. (Malvaceae/Helicteroideae/ Durioneae or Bombacaceae-Durioneae). Organisms Diversity \& Evolution 1(3): 165-178.

Nyffeler, R. \& Baum, D.A. 2000. Phylogenetic relationships of the durians (Bombacaceae-Durioinae or MalvaceaeHelicterioideae-Durionae) based on chloroplast and nuclear ribosomal DNA sequence. Plant Systematics and Evolution 224(1-2): 55-82.

Pearson, S.R. \& Brown, H.P. 1932. Commercial Timbers of India: Their Distribution, Supplies, Anatomical Structure, Physical and Mechanical Properties and Uses. Calcutta: Government of India, Central Publication Branch.

Refaat, J., Desoky, S.Y., Ramadan, M.A. \& Kamel, M.S. 2012. Bombacaceae: A phytochemical review. Pharmaceutical Biology 51(1): 100-130.

Richter, V.H.G. 1981. Anatomie Des Sekundaren Xylems Und Der Rinde Der Lauraceae. Hamburg: Verlag Paul Parey.

Salma, I. 2011. Durio of Malaysia. Kuala Lumpur: Malaysian Agricultural Research and Development Institute.

Schweingruber, F.H., Borner, A. \& Schulze, E.D. 2006. Atlas of Woody Plant Stems: Evolution, Structure and Environmental Modifications. New York: Springer Berlin Heidelberg.

Sneath, P.H.A. 1976. Phenetic taxonomy at the species level and above. Taxon 25(4): 437-450.

Ter Welle, B.J.H. 1976. Silica grains in woody plants of the Neotropics, especially Surinam. Dlm. Wood Structure in Biological and Technological Research, disunting oleh Baas, P., Bolton, A.J. \& Catling, D.M. Siri ke-3. Leiden: Leiden University Press, Leiden Botanical. hlm. 107142 .

Terada, K. \& Suzuki, M. 1998. Revision of the so-called 'Reevesia' fossil woods from the Tertiary in Japan-A proposal of the genus Wataria (Sterculiaceae). Review of Paleobotany and Palynology 103: 235-251.

Wheeler, E.A., Baas, P. \& Gasson, P.E. 1989. IAWA List of microscopic features for hardwood identification. IAWA Bulletin 10(3): 219-332.

Nordahlia Abdullah Siam*, Richard Chung Cheng Kong \& Lim Seng Choon

Institut Penyelidikan Perhutanan Malaysia

52109 Kepong, Selangor Darul Ehsan

Malaysia

\section{Noraini Talip}

Pusat Pengajian Sains Sekitaran dan Sumber Alam

Fakulti Sains dan Teknologi

Universiti Kebangsaan Malaysia

43600 UKM Bangi, Selangor Darul Ehsan

Malaysia

*Pengarang untuk surat-menyurat; email: nordahlia@frim.gov. my

Diserahkan: 19 Disember 2018

Diterima: 7 November 2019 